\title{
LENIN - IMPERIALISMO, INTERNACIONALISMO E REVOLUÇÃO
}

\author{
LENIN - IMPERIALISMO, INTERNACIONALISMO Y REVOLUCIÓN
}

\section{LENIN - IMPERIALISM, INTERNATIONALISM AND REVOLUTION}

DOI: ://dx.doi.org/10.9771/gmed.v12i2.38676

Muniz Ferreira ${ }^{1}$

Resumo: O objetivo do texto é destacar a relevância e a riqueza da contribuição de Lenin à tradição marxista, manifestada no aprofundamento de determinadas elaborações do marxismo clássico, como as análises dos processos de produção, circulação e reprodução ampliada do capital, luta de classes e perspectiva da revolução proletária, ditadura do proletariado e estado no período da transição ao comunismo. Além disto, Lenin contribui para o enriquecimento do marxismo através da resolução e/ou formulação de novos problemas, como os relacionados ao desenvolvimento capitalista em zonas "periféricas", a teoria da organização revolucionária e do partido de novo tipo e a articulação entre as revoluções proletárias e as lutas de libertação nacional.

Palavras-chave: Lenin. Tradição marxista. Revolução mundial.

Resumen: El objetivo del texto es resaltar la relevancia y riqueza de la contribución de Lenin a la tradición marxista. Tal contribución se manifiesta en la profundización de ciertas elaboraciones del marxismo clásico, como el análisis de los procesos de producción, circulación y reproducción ampliada del capital, la lucha de clases y la perspectiva de la revolución proletaria, la dictadura del proletariado y el estado en el período de transición al comunismo. Además, Lenin contribuyó para el enriquecimiento del marxismo a través de la resolución y / o la formulación de nuevos problemas, como los relacionados con el desarrollo capitalista en zonas "periféricas", la teoría de la organización revolucionaria y el partido de tipo y la articulación entre revoluciones proletarias y luchas de liberación nacional.

Palabras clave: Lenin. Tradición marxista. Revolución mundial.

Abstract. The aim of this text is to highlight the relevance and richness of Lenin's contribution to the Marxist tradition. Such contribution is manifested in the deepening of certain elaborations of classical Marxism, such as the analysis of the processes of production, circulation and expanded reproduction of capital, class struggle and perspective of the proletarian revolution, dictatorship of the proletariat and state in the period of transition to communism. In addition, Lenin contributed to the enrichment of Marxism through the resolution and / or the formulation of new problems, such as those related to capitalist development in "peripheral" zones, the theory of revolutionary organization and the new type party and the articulation between the proletarian revolutions and national liberation struggles.

Keywords: Lenin. Marxist tradition. World revolution 


\section{Lenin na tradição marxista}

Lenin, cujo nome verdadeiro era Vladimir Illytch Ulianov, nasceu na cidade de Simbirsk (rebatizada em sua homenagem Ulianovsky, em 1924) no dia 22 de abril de 1870, portanto, há 150 anos. Foi, provavelmente, o pensador que, após o desaparecimento de Marx e Engels — fundadores da tradição marxista - mais contribuiu para o desenvolvimento da teoria e da prática revolucionárias até os nossos dias. Esta contribuição possui um caráter multifacetado e inovador. Lenin retomou, continuou e aprofundou formulações, análises e proposições já realizadas pelos expoentes do marxismo clássico, como o estudo dos processos de formação, circulação e reprodução ampliada do capital, a análise da luta de classes e a projeção das perspectivas da revolução proletária. Conduziu também a reflexão marxista a territórios ainda não frequentados, contribuindo de forma fundamental com a resolução de problemas que Marx e Engels não conseguiram ou não tiveram tempo de solucionar. Entre estes temos, por exemplo, o desenvolvimento do capitalismo nas regiões “periféricas” do planeta.

Marx e Engels, com raras e pouco conhecidas exceções, concentraram atenção no estudo do desenvolvimento do capitalismo nas zonas economicamente mais avançadas do ponto de vista da objetivação histórica deste modo de produção, tomando o Reino Unido como referência fundamental para a elaboração de $\mathbf{O}$ capital. Lenin, diferentemente, se dedicou pioneiramente ao estudo do desenvolvimento do capitalismo em uma área considerada "periférica" (ainda que tal expressão ainda não houvesse se imposto nos estudos econômicos), como era o caso de sua terra natal, a Rússia.

Lenin abordou com profundidade singular, para além das indicações iniciais legadas pelos iniciadores da tradição marxista, o tema da organização revolucionária. Interpretando com acuidade as circunstâncias políticas de seu tempo, distintas daquelas vivenciadas por Marx e Engels e das conhecidas pela social-democracia ocidental, elaborou e pôs em prática um novo conceito de organização política, o partido operário de novo tipo.

Dando seguimento às investigações marxianas acerca das tendências à concentração e monopolização intrínsecas ao processo de reprodução ampliada do capital em seu estágio de livre concorrência - estudos continuados no começo do século XX por outros autores, como Hobson, Hilferding, Luxemburg, Kautsky, Bukharin —, Lenin produziu a mais complexa e completa interpretação sobre o ingresso do capitalismo em sua fase imperialista e as implicações econômicas, sociais e políticas daí resultantes.

A partir das formulações dos fundadores do marxismo acerca da necessidade da conquista do poder pelo proletariado, da conversão da mudança do caráter de classe do estado e sua utilização para a expropriação da burguesia e transferência dos meios de produção aos trabalhadores na primeira fase da 
transição ao comunismo, Lenin enriqueceu, tanto de forma teórica quanto prática, a compreensão marxista acerca da forma e das funções do estado proletário no período transicional.

Lenin também desenvolveu, de forma profundamente inovadora, uma teoria sobre a combinação das revoluções proletárias vitoriosas nas metrópoles do capital e aquilo que veio a ser conhecido como as revoluções de libertação nacional dos povos oprimidas da América Latina, África e Ásia como o caminho por excelência para o triunfo da revolução mundial.

Lenin foi, sobretudo, o pensador mais bem sucedido em combinar adequadamente a elaboração teórica e a atividade revolucionária prática, realizando, como nenhum outro, a síntese dialética contida na expressão filosofia da práxis, popularizada por um de seus mais importantes discípulos, Antonio Gramsci. Tal síntese encontra-se expressa de forma precisa na máxima lenineana, segundo a qual "sem teoria revolucionária não há prática revolucionária”.

\section{Lenin e seu estudo sobre o desenvolvimento do capitalismo na Rússia}

Ainda muito jovem, antes de completar trinta anos de idade, Lenin redigiu aquela que, possivelmente, é a primeira experiência de análise marxista de uma formação social determinada, realizada por discípulos de Marx e Engels. Trata-se de uma obra de referência para o estudo da Rússia prérevolucionária até os dias de hoje. É interessante constatar que nenhum marxista anterior (fosse ele francês, alemão, belga, etc.,) submetera sua própria formação social a uma análise deste tipo. Isto talvez nos revele o caráter predominantemente doutrinário e escolástico do marxismo da II Internacional. Lenin pode ter sido o primeiro marxista a utilizar o método, o conceitual, portanto, o instrumental de análise marxista para a realização daquilo que ele definiu, em outros momentos de sua obra, como a análise concreta da realidade concreta para além da mera repetição de fórmulas já reconhecidas e consagradas no âmbito da tradição. Assim, desde de cedo, foi um marxista singular e original.

O trabalho de Lenin, porém, não investigou apenas uma formação social específica. Muito mais que isto, ele se debruçou sobre o que nós chamaríamos hoje de uma totalidade socioeconômica "periférica", na qual as relações capitalistas ainda ocupavam um lugar subordinado frente às relações de produção de tipo "semifeudal” (grande propriedade latifundiária). Logo, uma espécie de sociedade não centralizada na atenção de Marx e Engels. Hoje, sabemos que, na segunda metade dos anos 70 do século XIX, Marx se dedicara a estudos sobre a economia e a sociedade de países como a própria Rússia e a Turquia. Porém, poucos registros, além de breves alusões epistolares, foram legados à posteridade.

A formação social russa investigada por Lenin foi um caso do que veio a ser conhecido como “capitalismo tardio". Lá, as relações de produção capitalista só encontrariam espaço propício ao seu desenvolvimento nas últimas décadas do século XIX. Para que se tenha uma ideia, as relações de servidão feudal só foram abolidas legalmente no país, em 1861. No entanto, não tendo conhecido uma revolução burguesa clássica nem mesmo um processo ostensivo de "modernização conservadora" organizado a 
partir do estado, a economia e a sociedade russas caracterizavam-se pela sobrevivência de sólidas reminiscências feudais e semifeudais, como mencionado anteriormente.

Não obstante, em algumas partes do território do império, particularmente no entorno da capital São Petersburg, verificara-se um processo de industrialização marcado pela presença de grandes indústrias e com expressiva concentração de operários. Boa parte destas indústrias era de procedência estrangeira, assim como o sistema financeiro existente no país, que tinha entre seus principais expoentes instituições bancárias de capital inglês, francês, alemão e estadunidense. Deste modo, o polo dinâmico do capitalismo russo era protagonizado pelo capital internacional, que subordinava a economia do país, tornando-a dependente dele. Isto, por sua vez, gerava uma contradição entre a condição russa de grande império territorial expansionista e dominador, potência militar integrada ao centro do sistema de poder internacional então em vigor e sua formação socioeconômica "periférica" e subordinada no âmbito da economia mundial.

O resultado do estudo de Lenin já apontava para a caracterização do desenvolvimento do capitalismo como um processo "desigual e combinado" - conquanto esta terminologia ainda não fosse utilizada (encontra-se aqui o embrião de uma ideia desenvolvida a posteriori em sua obra sobre o imperialismo, que inspiraria os formuladores da versão marxista da "Teoria da Dependência") - e, ao fazê-lo, enriquecia o pensamento marxista com a proposta de uma tese consoante a qual o desenvolvimento do capitalismo se efetivaria com amplitudes, dinâmicas e ritmos diferentes, não apenas nos marcos da economia mundial, mas também no âmbito de uma mesma formação social. Elaboração esta completada e aprofundada ulteriormente em sua obra sobre o imperialismo. Temos aqui também a enunciação embrionária dos elementos conceituais para as futuras interpretações sobre a chamada dualidade estrutural das sociedades capitalistas "periféricas" — e mesmo das extrapolações, estranhas à obra de Lenin e resultantes de uma leitura esquemática da mesma - , que, nos anos da Internacional Comunista, identificaria nos países "coloniais e semicoloniais" da América Latina, África e Ásia, a combinação de relações de produção capitalistas e reminiscências semifeudais.

Nestes escritos temos também a antecipação da tese acerca da incapacidade da burguesia em dirigir a revolução burguesa na Rússia, tema elaborado de maneira acabada em seu livro Duas táticas da social-democracia na revolução democrática, o qual abordarei mais adiante. Do caráter subordinado e tardio do capitalismo russo adviria um caráter não revolucionário da burguesia, incapaz de empreender, em seu país, as transformações que suas congêneres realizaram em algumas sociedades ocidentais.

Tais análises contribuíram para solucionar os debates teóricos e culturais entre intelectuais e ativistas políticos "eslavófilos" e "ocidentalistas", "narodniques (Populistas)" e "social-democratas". Os culturalistas eslavófilos e os revolucionários narodniques negavam-se a reconhecer a profundidade das consequências geradas pela penetração das relações capitalistas na formação social russa. Colocando-se em uma posição nostálgica e romântica, idealizavam as virtudes da comuna agrária camponesa russa (o mir) e superestimavam sua sobrevivência e relevância na sociedade daquele país. Ao fazerem isto, vislumbravam 
uma via completamente original para o desenvolvimento histórico da sociedade russa e rejeitavam as proposições do socialismo marxista para a condução do processo de emancipação política, econômica e social dos trabalhadores e do povo russo.

Os estudos e elaborações lenineanas subvertiam completamente esta concepção. Eles enunciavam a irreversibilidade da penetração do capitalismo na sociedade russa, dissolvendo amplamente a comuna agrária "primitiva" (o mir), que para os "eslavófilos" e populistas constituiria o embrião de um socialismo "autenticamente russo, distinto do socialismo ocidental". Segundo Lenin, o avanço do capitalismo na Rússia formava um proletariado urbano industrial, cuja ação política (e não puramente econômica) protagonizaria a revolução política que derrubaria a autocracia russa e desenvolveria o processo da revolução burguesa no país.

Ademais, a enunciação lenineana do protagonismo do proletariado russo nas revoluções que deveriam conduzir a emancipação dos povos daquele país confrontava também o pensamento de setores situados à direita da própria corrente social-democrata. Influenciados pelo reformismo da ala direita da socialdemocracia ocidental, os "economicistas" russos negligenciavam não apenas a luta pelo papel hegemônico do proletariado na revolução burguesa, mas até sua dedicação à própria luta política. E foi em polêmica com este tipo de perspectiva que Lenin desenvolveria a sua teoria do partido operário de novo tipo.

\section{Lenin e o partido operário de novo tipo}

Marx e Engels não conheceram senão os primórdios da formação de grandes partidos operários de massa. Engels - que, por viver mais tempo, testemunhou o crescimento do Partido Social-democrata Alemão e da II Internacional - consumiu boa parte de suas energias tentando retificar as tendências reformistas daquelas organizações. Já os líderes da social-democracia posteriores a Engels comprometeram-se inteiramente com o projeto de edificação e gestão de grandes partidos operários de massas voltados, principalmente, para a atuação político-parlamentar nos marcos dos sistemas liberalrepresentativos, em processo de ampliação gradual, nos países de capitalismo mais desenvolvido da Europa Centro Ocidental.

Lenin teorizou e colocou em prática pioneiramente um novo modelo de partido político operário e revolucionário adaptado às condições de vigência da autocracia russa e sua inclemente repressão contra os trabalhadores e o povo. Neste novo modelo, o partido proletário deveria se organizar ilegalmente, dominar todas as técnicas do trabalho conspirativo e clandestino, apoiar-se sobre um núcleo de revolucionários profissionais e treinar seus quadros nos métodos da agitação e da propaganda. Tal proposta organizativa - que, convém frisar, respondia às exigências geradas pela vigência do sistema despótico de estado que existia na Rússia — representava uma alternativa original (iconoclasta para 
alguns) ao modelo dos partidos legais de massas voltados prioritariamente para a atividade parlamentar então adotado pela social-democracia da Europa Ocidental, como visto acima.

Lenin não era carbonário e nem blanquista. Tinha consciência de que as transformações revolucionárias necessárias à sociedade russa não se realizariam senão pela ação organizada das grandes massas de trabalhadores da cidade e do campo. Em momento algum advogou que um pequeno número de revolucionários poderia substituir a atuação das classes. Por outro lado, também se distanciava daqueles que, supervalorizando e fetichizando supostas disposições revolucionárias inatas ao conjunto do proletariado, rejeitavam a necessidade de uma organização de vanguarda, capaz de interpretar a realidade da luta de classes, formular os objetivos imediatos e de longo prazo e impulsionar a mobilização revolucionária da classe trabalhadora.

Ao elaborar tal teoria, Lenin resgatou também a centralidade do sujeito da ação revolucionária, secundarizado e menosprezado nas abordagens de viés evolucionista/reformista de boa parte das lideranças da social-democracia da Europa ocidental. Tais abordagens, de forte conteúdo economicista, concebiam o desenvolvimento histórico das sociedades capitalistas como um processo lógico, no qual, à medida que se desenvolvem as forças produtivas materiais, geram-se também as condições objetivas para a superação deste modo de produção, quase sem necessidade da intervenção revolucionária das massas. Nesta concepção, as tarefas do partido operário consistiam fundamentalmente em organizar e educar a classe nos sindicatos e organizações social-democratas, participar dos pleitos eleitorais e elaborar leis que ampliassem os direitos e elevassem sistemática e gradualmente as condições de vida dos trabalhadores. O socialismo, assim, adviria de um esgotamento lógico e quase natural das possibilidades do capitalismo desenvolver indefinidamente as forças produtivas e elevar as condições materiais da população.

Com sua teoria do partido de vanguarda, Lenin recuperou, para o socialismo internacional, a imprescindibilidade do elemento subjetivo na superação do capitalismo. Enfatizando que o desenvolvimento do capitalismo só gera mais capitalismo e que só a atividade política das classes revolucionárias poderia superá-lo, recuperou e elevou a um patamar superior os nexos entre a teoria e a prática revolucionárias presentes nas formulações dos iniciadores da tradição marxista aparentemente esquecida por toda uma geração de líderes socialistas. Tendo vivido a totalidade (Marx) ou a maior parte (Engels) de suas vidas em uma Europa na qual a privação dos direitos de participação e representação política para os trabalhadores se assemelhava às condições ainda vigentes na Rússia do século XX, dedicaram todos os seus esforços para a conscientização, organização e mobilização dos trabalhadores, visando à ruptura revolucionária.

\section{Lenin e a teoria da revolução ininterrupta}

Em sua obra de polêmica Duas táticas da social-democracia na revolução democrática, de 1905, Lenin retomou e aprofundou as formulações de Marx (Manifesto do partido comunista e A 
burguesia e a contrarrevolução, ambos de 1848) sobre o papel desempenhado pela burguesia em processos revolucionários nos quais o proletariado já atuava, potencialmente, como ator protagonista.

Lembremos que, como dito antes, na maior parte da época que Marx viveu e escreveu a grande maioria dos estados europeus, mesmo na parte ocidental do continente, ainda vivia sob a égide de regimes de tipo aristocrático. O predomínio deste tipo de governo decorria da contrarrevolução e se estabelecera no continente europeu após a derrota definitiva das tropas napoleônicas em 1815 e consagrou-se no Congresso de Viena, neste mesmo ano. O recrudescimento do status quo aristocrático e absolutista ao estilo do ancient règime no velho continente recolocara na ordem do dia a luta pela reconquista das liberdades e direitos democráticos característicos das revoluções burguesas. Isto, porém, ocorria em uma época histórica na qual o operariado já se constituíra como classe no plano continental e colocava diante de si objetivos revolucionários próprios. Foi neste contexto que Marx, nos escritos citados e outros, prognosticou o advento de uma nova série de revoluções no continente europeu. Tais revoluções, por sua agenda antiaristocrática, republicana e democrática, teriam inicialmente um caráter burguês. Mas, ao colocar as massas em movimento e acionar as energias revolucionárias do proletariado, propiciariam as condições para que estas mesmas revoluções se convertessem processualmente em revoluções proletárias de alcance continental.

Quase meio século depois, recuperando o cerne de suas próprias interpretações acerca do caráter subordinado e caudatário da burguesia russa diante da aristocracia territorial e da autocracia tzarista, Lenin enfatiza a tese do caráter não revolucionário daquela classe. Como consequência disto, elabora a ideia de que a revolução burguesa na Rússia só poderia triunfar se conduzida sob a hegemonia das classes efetivamente revolucionárias daquela sociedade, ou seja, o proletariado e o campesinato. Pensador profundamente dialético, Lenin não via nisto qualquer contradição, compreendia nitidamente que o caráter de uma revolução é definido pelas tarefas cumpridas por ela e não necessariamente pela origem social daqueles que a conduzem. Sendo as tarefas da revolução burguesa russa a eliminação da autocracia imperial e o fim do monopólio da propriedade da terra pela aristocracia territorial e estando a burguesia incapacitada de dirigir consequentemente tal tarefa, caberia à aliança operário-camponesa assumir a direção do processo.

Como resultado desta direção, o poder político originado não seria uma democracia burguesa de tipo euro-ocidental orientada ao aprofundamento do capitalismo russo, mas sim uma "ditadura democrático-revolucionária" do proletariado e do campesinato pobre, que se desdobraria ulteriormente em uma revolução proletária orientada ao socialismo. Uma breve observação deve ser feita em relação à riqueza e originalidade daquele conceito. O revolucionário russo, assim como seus antecessores jacobinos, democratas revolucionários e socialistas (incluindo aí Marx e Engels), jamais identificou o conteúdo essencial do conceito de democracia, com tardias apropriações e reelaborações liberais. Nestas últimas apropriações — presentes na época de Lenin, mas que só se tornariam amplamente hegemônicas no curso dos séculos XX e XXI —, o conceito de democracia seria desfigurado e rebaixado para designar, em 
primeiro lugar, as liberdades individuais e segundamente os procedimentos político-formais característicos da institucionalidade liberal-representativa, como separação entre poderes, eleições periódicas, atuação de partidos políticos, alternância do poder, etc.

Para Lenin, o conceito de democracia deveria ser compreendido em sua acepção etimológica original, uma combinação dos conceitos de demo (povo) e cratos (poder). Democracia seria, portanto, um regime político caracterizado pelo exercício do poder pelo povo. Um exercício só realizável se as massas trabalhadoras gozassem das mais amplas liberdades políticas. A livre organização dos trabalhadores e a adoção do sufrágio universal seriam instrumentos para o exercício desta ditadura democrática. Já o conceito de ditadura, tal como fora compreendido pelos fundadores da tradição marxista, partia de seu sentido original, exercício do poder com atribuições excepcionais, por um período limitado de tempo, passando a designar a essência mesma de todas as formas de estados dotados de recursos repressivos e dedicados a sua utilização. Mais do que isto, a compreensão do estado como um instrumento de dominação em uma sociedade dividida em classes também realça a sua essência ditatorial. Ora, nas condições da vigência da luta de classes, o recurso aos instrumentos e práticas repressivas para a conservação do poder e a realização dos objetivos econômicos e sociais das classes à frente do estado são procedimentos absolutamente normais. Daí a lógica complementariedade entre democracia e ditadura na essência dos estados políticos nas sociedades de classe. Além disto, para além de qualquer idealização acerca da possibilidade de um desenvolvimento pacífico do processo revolucionário, Lenin também compreendia que a revolução burguesa dirigida pela aliança operário-camponesa na Rússia só conseguiria atingir os seus objetivos de acabar com tsarismo e eliminar o monopólio da propriedade da terra se utilizasse o poder coercitivo do estado revolucionário para reprimir a contrarrevolução e expropriar a aristocracia territorial.

Cabe lembrar que, quando Lenin desenvolveu suas elaborações nem o mais liberal dos estados ocidentais praticava o sufrágio universal. Mesmo nas sociedades consideradas mais livres, existiam restrições às atividades de sindicatos e partidos operários, leis repressivas contra greves, censura a publicações, para não falar da completa privação dos direitos políticos das mulheres.

Ao defender que a revolução burguesa russa deveria ser dirigida pela aliança operário-camponesa, instituindo uma ditadura democrático-revolucionária do proletariado e dos camponeses pobres, Lenin realizava o aprofundamento de uma tese apenas esboçada por Marx, a da transformação de uma revolução burguesa em revolução proletária em um processo ininterrupto, que teria como estação de chegada a revolução proletária.

Inversamente, no âmbito da social-democracia ocidental e na ala direita da socialdemocracia russa (mencheviques) prevalecia uma leitura muito pouco dialética, segundo a qual uma revolução burguesa deveria ser dirigida necessariamente pela burguesia. Mais que isto, separavam, sob o ponto de vista histórico-político, a revolução burguesa da revolução proletária, estabelecendo rigidamente a primazia processual da primeira em relação à segunda, antecipando o esquema das duas revoluções dissociadas e sucessivas, que reapareceria mais tarde no próprio movimento comunista. Estas diferentes concepções 
acerca do desenvolvimento do processo revolucionário russo implicavam na proposição de diferentes políticas de aliança. À ideia de uma revolução burguesa dirigida pela burguesia e apoiada pelo proletariado correspondia uma política de alianças preferencial entre os socialdemocratas e os representantes políticos da burguesia liberal (Democratas Constitucionais, ou Cadetes). A compreensão de que a revolução burguesa na Rússia, para ser vitoriosa, deveria ser dirigida pela aliança operário-camponesa, conduzia a uma aliança preferencial com os representantes do campesinato russo (Socialistas-revolucionários, ou esseristas). Tais divergências contribuiriam decisivamente, nos anos 1907-1912, para o alargamento da distância política que separaria Lenin e seus partidários do menchevismo russo até a divisão em dois partidos com nomes semelhantes e políticas bem diferentes: POSDR (mencheviques) X POSDR (bolcheviques). Desempenharia também um papel fundamental na polêmica teórica entre Lenin e Kautsky na sequência da Revolução de Outubro, como veremos mais adiante.

\section{A teoria do imperialismo}

Se Lenin foi provavelmente o primeiro estudioso a utilizar as categorias e os instrumentos de análise de Marx para o estudo de uma formação social particular, foi também aquele que levou o estudo dos processos de monopolização do capital a suas consequências mais elevadas, apesar de não ter sido o único e nem mesmo o primeiro a realizar este segundo tipo de investigação.

O conceito de imperialismo foi utilizado, pela primeira vez, em sua acepção corrente, por um economista inglês de formação liberal chamado J. A. Hobson. Sendo um liberal, viu no imperialismo um desvio de percurso em relação aos valores considerados sagrados das livre iniciativa e livre concorrência. Interessado em salvar a economia de mercado desta suposta distorção, preconizou a elaboração pelos parlamentos e a adoção pelos governos de leis antimonopolistas, capazes de restaurar os princípios liberais vilipendiados no processo. Outros autores, inclusive marxistas como Rosa Luxemburg, Hilferding, Kautsky e Bukharin, também analisaram o fenômeno, produzindo obras que foram utilizadas por Lenin por ocasião da elaboração de seu estudo. O diferencial da obra de Lenin, porém, decorre da consistência lógico-conceitual impressa em sua interpretação ao identificar, no advento do imperialismo, um processo orgânico e estrutural do desenvolvimento do modo de produção capitalista com consequências históricas de alcance excepcional. Ela foi, e muito provavelmente ainda é, a mais completa e penetrante análise marxista da economia capitalista mundial. Sua influência alcançou um nível extremamente elevado dentro e fora da tradição marxista a ponto de eclipsar, em grande medida, os escritos de seus antecessores.

Redigida no calor da Primeira Guerra Mundial, procura tanto explicar o conflito através do estudo dos fatores dinâmicos do desenvolvimento do capitalismo em sua (nova) fase monopolista, quanto oferecer elementos à avaliação de suas possíveis implicações para o desenvolvimento da luta revolucionária. Seria impossível reproduzir aqui toda a complexa compreensão de Lenin sobre os processos de internacionalização global das relações capitalistas e da subsunção de outras relações de produção e formações sociais à lógica e à dinâmica dos processos de reprodução ampliada do capital. 
Revelação segundo a qual o capitalismo, ao "globalizar" seus mecanismos e processos de exploração e dominação, internacionaliza suas contradições e conflitos, mundializando a luta de classes e potencializando a revolução mundial. Porém, uma das formulações mais importantes e repletas de implicações para a ação revolucionária é a caracterização do imperialismo como apogeu e início do declínio do capitalismo enquanto modo de produção. O papel crescente do capital financeiro, a inevitabilidade do acirramento das disputas pelos mercados internacionais e as guerras daí decorrentes, a substituição da livre competição pela monopolização da economia evidenciam os aspectos mais opressivos, espoliadores e destrutivos do capitalismo em sua fase imperialista. A subordinação da produção à lógica especulativa, a amplitude sem precedentes dos efeitos de suas crises econômicas, a concentração, jamais vista, de capital, meios de produção e propriedades, a destrutividade inimaginável de suas guerras inevitáveis conflitavam de tal maneira com os interesses dos trabalhadores e dos povos do mundo que colocavam na ordem do dia a necessidade histórica de sua superação.

Em sua interpretação, Lenin também aprofundava uma nova perspectiva, já enunciada pelo Marx maduro, segundo a qual o início do processo de ruptura da ordem capitalista no plano internacional não precisaria, forçosamente, ocorrer em seu polo mais avançado de desenvolvimento econômico, mas poderia se dar a partir de uma área periférica, onde suas contradições se mostrassem mais agudas, onde se encontrasse o seu "elo mais fraco" e onde a atuação das vanguardas revolucionárias possuísse um nível de desenvolvimento, organização e capacidade de mobilização das massas trabalhadoras em condições de dirigir a revolução.

Foi de posse deste entendimento que ele logrou organizar e dirigir a ruptura revolucionária russa de outubro de 1917.

\section{A experiência original dos sovietes e o estado transicional na Rússia revolucionária}

Lenin não idealizou (projetou) nem criou os sovietes. Porém, compreendeu e soube explorar como ninguém suas potencialidades no processo revolucionário russo. Em um sistema político, no qual partidos e sindicatos operários encontravam-se impossibilitados de atuarem livremente, os sovietes (conselhos) desempenharam um papel central na arregimentação e mobilização das energias revolucionárias das massas populares (operários, camponeses e soldados).

Fenômeno original na história das lutas e revoluções proletárias, os sovietes russos desempenharam alternadamente o papel de órgãos de exercício do duplo poder por parte das massas revolucionárias e base da ditadura do proletariado no estado revolucionário. A função de órgãos de exercício de um duplo poder por parte das massas trabalhadoras foi ensaiada, digamos assim, no curso da revolução russa de 1905, mas realizado em sua completude após o triunfo da revolução de fevereiro/março de 1917. Neste segundo processo, os conselhos de operários, camponeses e soldados funcionaram como instrumentos para a prática da democracia direta e polo de poder político alternativo 
ao governo provisório, no qual predominavam as forças da oposição liberal coligadas com a ala direita da socialdemocracia russa. Nesta condição, os sovietes foram identificados por Lenin como a base social e o alicerce político fundamental para a constituição do novo tipo de estado proletário revolucionário que concretizaria as tarefas da revolução naquele país. Demonstrando um talento incomum em sintetizar complexa elaboração teórico-política em uma palavra de ordem mobilizadora de massas, o lema lenineano "todo poder aos sovietes" foi um impulsionador extraordinário da ação revolucionária dos operários camponeses e soldados russos na Revolução de Outubro de 1917.

Ao atribuir-lhes esta função basilar, Lenin pretendia resolver, nas condições específicas da revolução na Rússia, os problemas legados pelo silêncio de Marx e Engels em relação aos aspectos mais concretos do estado de transição do capitalismo ao socialismo e ao comunismo. Ao fazê-lo, aportava mais uma vez uma contribuição enriquecedora ao acervo prático e intelectual da tradição marxista para além das indicações incompletas deixadas por seus próprios fundadores.

As duas obras formuladas por Lenin no contexto e sequência dos acontecimentos de 1917 (O Estado e a revolução, de agosto de 1917 e A ditadura do proletariado e o renegado Kautsky, novembro de 1918) constituem a contribuição lenineana ao problema do estado transicional. Teoria que articula a enunciação do protagonismo das massas revolucionárias organizadas nos sovietes e a direção do estado pelo partido bolchevique, depois comunista.

Para defender esta combinação, Lenin polemizou tanto à direita quanto à esquerda. A sua direita, combateu as teorias etapistas (primeiro a revolução burguesa, dirigida pela burguesia, depois a proletária, liderada pelos socialistas) e evolucionistas/positivistas (a Rússia não está madura para uma revolução proletária) provenientes da direita e do centro socialdemocrata (Kautsky, os mencheviques, etc.). A sua esquerda, confrontou os posicionamentos dos "comunistas de esquerda" ou "conselhistas" (Anton Panenköek, Otto Rühle, Karl Korsch), que superestimavam o papel dos conselhos operários na revolução, rejeitando o papel do partido e preconizando a extinção imediata do Estado. No decurso destes últimos combates elaborou aquela que talvez seja a mais completa e profunda crítica ao ultra esquerdismo desde a polêmica de Marx e Engels com os anarquistas (A doença infantil do esquerdismo no comunismo, maio de 1920).

\section{A contribuição de Lenin às lutas dos povos, nações e nacionalidades oprimidas}

A teoria do imperialismo de Lenin ofereceu os fundamentos analíticos e conceituais para a resolução de um dilema vivido pelo socialismo internacional desde os primórdios da II Internacional.

Antes das formulações de Lenin, subsistiam ambiguidades no seio do socialismo internacional acerca do posicionamento a ser adotado em face do colonialismo e daquilo que chamamos hoje de lutas de libertação nacional. Uma direita socialista, hipertrofiando e descontextualizando juízos elaborados tanto por Marx quanto por Engels, partia da ideia de que os socialistas deveriam encarar a problemática colonial 
com critérios estritamente objetivos e não emocionais, argumentava que a atuação de algumas lideranças da resistência anticolonial tinha por objetivo apenas recuperar o direito de explorar com exclusividade os povos das colônias, eximindo-se assim de apoiar aquelas lutas. Seus representantes mais exaltados chegavam a incorporar em seus discursos mistificações sobre o papel civilizador das metrópoles e coisas do gênero. Procurando tingir de socialista suas posições objetivamente pró-colonialistas, prenunciava que, uma vez tendo alcançado o poder político nas metrópoles coloniais, a classe operária triunfante levaria aos povos coloniais os benefícios das políticas socialistas colocadas em prática em seus países de origem, iniciando então um processo, de duração indefinida, de preparação destes povos "incivilizados" ou "semicivilizados" para uma eventual emancipação nacional.

Já a ala mais "centrista da social-democracia", partindo de pressupostos semelhantes, enfatizava sua falta de disposição em manter o domínio colonial dos povos que se levantassem contra ele, sob o argumento de que não caberia ao proletariado travar guerras coloniais. Enunciavam que, em face das lutas anticoloniais, deveriam adotar uma política de laissez faire, laisser passer... Apenas na minoritária esquerda socialista, da qual participavam quadros revolucionários como Lenin, Rosa Luxemburg e o inglês Belfort Bax, predominava um decidido posicionamento anticolonialista de apoio ativo às lutas de libertação nacional.

Lenin, ao formular a tese do caráter eminentemente internacional do capitalismo em sua fase monopolista e associar a existência do sistema colonial ao exercício do poder da burguesia imperialista mundial, lançou as bases teórico-políticas para o estabelecimento de uma sólida conexão entre as lutas proletárias e as revoluções de libertação nacional. Foi o primeiro a sustentar de forma programática (tanto no âmbito do partido quanto da III Internacional) e sem qualquer ambiguidade o princípio do direito dos povos, nações e nacionalidades oprimidas à autodeterminação. Sendo o capitalismo em sua fase imperialista um ente histórico parasitário, destituído de qualquer caráter "civilizatório" ou progressista, a luta contra todos os imperialismos e, prioritariamente, o da própria nação dos revolucionários envolvidos passou a ser vista como um dever fundamental. Foi sob a inspiração destas concepções, que a III Internacional, organizada sob a direção de Lenin, inscreveu no programa do comunismo internacional o dever de apoiar ativamente as lutas de libertação dos povos oprimidos. Por iniciativa do próprio Lenin, a Internacional, já no início de sua trajetória, instituiu organismos destinados a analisar, formular programas e pôr em prática ações concretas de apoio às lutas dos povos "coloniais" e "semicoloniais" das áreas "periféricas" do globo (América Latina, África e Ásia).

\section{As teses de Lenin sobre a questão nacional e colonial}

Em suas "Teses para o II Congresso da Internacional Comunista" (1920), no tópico intitulado "Esboço inicial das teses sobre o problema nacional e colonial”, item 2, o teórico e revolucionário russo orientava a IC a "estabelecer sempre uma nítida diferenciação entre as nações oprimidas, dependentes, carentes de igualdade de direitos e as nações opressoras, exploradoras, soberanas, em oposição à mentira 
democrática burguesa que encobre a escravização colonial e financeira - própria da época do capital financeiro e do imperialismo - da imensa maioria da população da Terra por uma minoria insignificante de países capitalistas adiantados e muito ricos". (LENIN, 1977, p.120.)

Mais adiante, no item 9, orientava, “(...) todos os partidos comunistas prestem uma ajuda direta ao movimento revolucionário nas nações dependentes ou que não gozam de igualdade de direitos (por exemplo, Irlanda, entre os negros dos EUA, etc.) e nas colônias. Sem esta condição, de suma importância, a luta contra a opressão das nações dependentes e das colônias, assim como o reconhecimento de seu direito a emancipar-se e formar um Estado a parte, segue sendo um rótulo falacioso, como vemos nos partidos da II Internacional." (LENIN, 1977 p.123).

\section{Os leninistas do mundo colonial e as lutas de libertação nacional}

Ho Chi Minh foi um líder comunista vietnamita e principal articulista da luta do Vietnã contra o domínio colonial francês. Em O caminho que me conduziu ao leninismo (abril de 1960), dizia o revolucionário vietnamita:

Imediatamente a seguir à Primeira Guerra Mundial, eu trabalhava como assalariado em Paris (...). Eu estimava e respeitava Lênin simplesmente porque ele era um grande patriota que tinha libertado os seus patriotas; até então, eu não havia lido nenhuma de suas obras (...) Eu tinha aderido ao Partido Socialista Francês, simplesmente porque esses Senhores-Senhoras (eu chamava assim os camaradas do Partido) tinham testemunhado simpatia para com a luta dos povos oprimidos. Eu não compreendia o que era um partido, um sindicato, o que significava socialismo ou comunismo (...) A questão que me preocupava - e precisamente a que não se discutia durante essas reuniões era: Qual era a Internacional que apoiava a luta dos povos oprimidos? (...). No princípio, foi o patriotismo e não o comunismo que me levou a acreditar em Lenine e na terceira Internacional. Pouco a pouco, progredindo passo a passo, no decurso da luta, combinando o estudo teórico do marxismo-leninismo com o trabalho prático, compreendi que só o socialismo e o comunismo podem libertar os oprimidos e os trabalhadores do mundo inteiro. (MINH, 1976, p.72-73).

\section{O Leninismo e as lutas de libertação na África, os casos de Kwame Nkrumah e Amílcar Cabral}

No preâmbulo de sua obra Neocolonialismo, último estágio do imperialismo, que já no título paga tributo à obra de Lenin, ao mesmo tempo em que se propõe "atualizá-la" a partir de uma visão panafricana e terceiro mundista, na segunda metade do século XX (1967), o autor reproduz a seguinte citação de Lenin:

As enormes dimensões do capital financeiro concentrado na mão de uns poucos e criando uma rede extremamente extensa de laços íntimos e relações que envolvem não apenas os capitalistas pequenos e médios como também os muito pequenos, isso por um lado, e pelo outro a luta penosa contra grupos de financistas de outros estados nacionais pela partilha do mundo e o direito de dominar outras nações - esses dois fatores, tomados em conjunto, causam a conversão completa de todas as classes possuidoras para o lado do imperialismo. O sinal dos tempos é um entusiasmo "geral" quanto a suas perspectivas, uma defesa apaixonada do imperialismo e de toda a camuflagem possível de sua natureza real. (LENIN apud N'KRUMAH, 1977) 
Ativista político pela libertação das colônias portuguesas de Guiné e Cabo Verde, Amílcar Cabral foi o fundador do Partido Africano da Guiné Bissau e Cabo Verde (PAIGC) e o grande estrategista da luta armada de libertação nacional empreendida a partir de 1961. Em seu discurso na reunião cerimonial comemorativa do centenário do nascimento de Lenin, referiu-se a ele nos seguintes termos:

Camaradas e amigos! Para nós africanos, a morte já não é o fim da vida. Aqueles que deram a vida continuam a luta, eles vivem nos nossos corações como os combatentes mais consequentes e vigilantes, de cuja experiência nós tiramos a força. Esta filosofia encontra confirmação intensa nos nossos tempos, porque Lenine está sempre conosco, marchando ombro a ombro com todos os que desejam a paz, o progresso e a felicidade de todas as nações; Lenine vive no pensamento e na ação de todos os que, em vários cantos da Terra, lutam pela libertação dos seus países da dominação imperialista; Lenin ajuda-nos na luta pela libertação do Homem de todas as formas de dominação e exploração, pela vitória do humanismo em todo o mundo (...). Ao celebrar o centenário do nascimento de Lenine, nós sentimos que podemos prestar melhor homenagem à sua memória forjando e intensificando a unidade necessária para conseguir a vitória total na luta contra o imperialismo e para seguir o exemplo militante na sua firme lealdade aos princípios, na clareza das suas ideias e na sua aplicação incansável à realização do trabalho diário. (...) Glória a Lenin que nos deu um archote inextinguível na luta pela libertação nacional e social dos povos!'(CABRAL apud NIKARONOV, 1975, p.38).

\section{Conclusão}

Intérprete do imperialismo, estrategista da revolução mundial, 150 anos após o seu nascimento, Lenin vem sendo uma referência incontornável para boa parte daqueles que, tanto nas metrópoles do capital quanto nas zonas periféricas do mundo globalizado, dedicam seus esforços à conquista da emancipação nacional e social dos trabalhadores e povos explorados e oprimidos do mundo.

\section{Referências:}

ANDREUCCI, Franco. A questão colonial e o imperialismo. In HOBSBAWN, Eric J. (org.). História do Marxismo - v. 4. Rio de Janeiro: Paz e Terra, 1984.

DEL ROIO, Marcos. Lenin e a transição socialista. Lutas \& Resistências, Londrina, n.3, v.2, p. 67-82, $2^{\circ}$ sem. 2007.

FERREIRA, Muniz. Celebrar Outubro, problematizando. In PINHEIRO, Milton (org.). Outubro e as experiências socialistas do século XX. Salvador: Quarteto, 2010.

GRUPPI, Luciano. O pensamento de Lênin. Tradução de Carlos Nelson Coutinho. Rio de Janeiro: Graal, 1979.

HO CHI MIN. "O caminho que me conduziu ao leninismo", in Ho Chi Min - Escritos II (1954-1969). Lisboa: Edições Maria da Fonte, 1976.

LENIN, V.I. Obras escogidas en doce tomos. Moscou, Editorial Progreso, 1977.

LENIN, Vladimir Ilitch. "Duas tácticas da Social-democracia na Revolução Democrática", in Obras Escolhidas. Moscou: Editorial Progreso; Lisboa: Edições Avante!, 1977.

LENIN, Vladimir Ilitch. E1 Estado y la revolución. Moscou: Editorial Progreso, 1979.

LENIN, Vladimir Ilitch. A revolução proletária e o renegado Kaustsky. Tradução de Aristides Lobo. São Paulo: Livraria Editora de Ciências Humanas, 1979. 
N’KRUMAH, Kwame. Neocolonialismo último estágio do imperialismo. Rio de Janeiro: Civilização Brasileira, 1967.

NIKARONOV, Anatoli. Amilcar Cabral. Lisboa: Edições Sociais, 1975.

\section{Notas}

1 Professor Associado do Departamento de História da Universidade Federal Rural do Rio de Janeiro (UFRRJ), campus Seropédica. Doutor em História Econômica (USP). Pesquisador do Laboratório de Estudos em Relações Internacionais (LIERI/UFRRJ) e da Linha de Pesquisa sobre Sociedade, relações de poder e região do Programa de Pós- graduação em História da Universidade Federal da Bahia (PPGH/UFBA). Currículo Lattes: http://lattes.cnpq.br/3218494978727386. E-mail: ferreiramuniz8@gmail.com.

Recebido em: 04.08.2020 Aprovado em: 04.09.2020 